\title{
EFFICACY OF THREE CONDITIONS OF RADIOGRAPHIC INTERPRETATION FOR ASSESSMENT ROOT CANAL LENGTH
}

\author{
EFICÁCIA DE TRÊS CONDIÇÕES DE INTERPRETAÇÃO \\ RADIOGRÁFICA EM ODONTOMETRIA
}

Mitsuru OGATA ${ }^{1}$, Leonor de Castro Monteiro LOFFREDO², Milton Carlos KUGA ${ }^{3}$, Gulnara SCAF ${ }^{4}$

1- DDS. MSc, PhD, Assistant Professor, Department of Dentistry, Lins Dental School, Metodista University, Lins - SP, Brazil.

2- MSc, PhD, Associate Professor, Department of Public Health, Araraquara Dental School, São Paulo State University, Araraquara - SP, Brazil.

3- DDS. MSc, PhD, Assistant Professor, Department of Dentistry, Lins Dental School, Metodista University, Lins - SP, Brazil and Department of Dentistry, USC Dental School, University of Sagrado Coração , Bauru - SP, Brazil.

4- DDS. MSc, PhD, Associate Professor, Department of Oral Diagnosis and Surgery, Araraquara Dental School, São Paulo State University, Araraquara - SP, Brazil.

Corresponding address: Dr. Gulnara Scaf, Departamento de Diagnóstico e Cirurgia, Faculdade de Odontologia de Araraquara, Unesp. Rua Humaitá 1680. Cep.: 14801-903 Araraquara, São Paulo - Tel: (16) 3301-6364; Fax (16) 3301-6314 - E-mail: scaf@foar.unesp.br.

Received: September 1, 2004 - Modification: October 20, 2004 - Accepted: October 26, 2004

\begin{abstract}
$O$

bjective: To compare the efficacy of three conditions of image interpretation for radiographic root measurements and calculating the intra-observer reproducibility of the measurements. Material and methods: Thirty intra-operative periapical radiographs of maxillary central and lateral incisors were measured, in $\mathrm{mm}$, from the tip of the file to the radiographic apex, using a caliper. Three separate measurements were made of the 30 radiographs. The three measurements for each tooth were averaged and the mean used for further calculations. After a 12-day period, the measurements were repeated. The three experimental viewing conditions used: 1) standard viewbox without masking of background light around the radiograph and without magnification (Visual); 2) standard viewbox with use of a magnifying lens of 2.5x and with background light masked (Magnification); and 3) viewer device that restricts room lighting and enlarges the image by a magnifying lens of 1.75x (Viewer). The mean and standard deviation of the measurements were calculated and used for descriptive analysis. Two-way analysis of variance (ANOVA) was used to evaluate intra-observer and inter-method agreement of the measurements. The measurement error was estimated by Dalhberg's formula. Results: The ANOVA showed no significant differences between measurement sessions, viewing methods, or interaction between observation session and method ( $>>0.05$ ). The intra-observer measurement error was $0.02 \mathrm{~mm}$ for Visual and the Magnification methods and $0.01 \mathrm{~mm}$ for the Viewer. Conclusion: There does not seem to be any advantage in using viewbox masking or magnification for measuring the distance between the end of the endodontic file and the root apex in maxillary incisors. Uniterms: Odontometry; Radiographic image interpretation; Radiographic magnification; Reproducibility of results.
\end{abstract}

\footnotetext{
RESUMO

$O$ bjetivo: Comparar a eficácia de três condições de interpretação radiográfica em odontometria e avaliar a concordância intra-observador. Material e Método: Trinta radiografias periapicais de incisivos central e lateral superiores, de arquivos foram medidas, em mm, da extremidade da lima ao ápice radiográfico, com a utilização de um paquímetro digital. Foram feitas três medidas em cada radiografia e em seguida foi calculada a média. Após um período de 12 dias, as medidas foram repetidas. As três condições experimentais de interpretação radiográfica foram: negatoscópio sem máscara e sem magnificação (Visual); 2) negatoscópio com lente de aumento de 2,5 X e com máscara (Magnificação) e 3) bloqueador de luz e lente de aumento de 1,75 X (Bloqueador). As médias e os desvios-padrão das medidas foram calculados e realizada uma análise descritiva. Foi utilizada a análise de variância a dois critérios (ANOVA) para avaliar a concordância intra-observador e intramétodo. O erro das medidas foi calculado pela fórmula de Dalhberg. Resultados: O teste ANOVA não mostrou diferenças significantes entre as duas sessões de observação, métodos de interpretação ou interação entre as sessões de interpretação e método ( $>0,05)$. A medida intraobservador foi 0,02 mm para os métodos Visual e Magnificação e 0,01 mm para o Bloqueador. Conclusão: Parece não haver qualquer vantagem realizar medidas da distância entre o ápice radicular e o extremo da lima endodôntica em dentes incisivos superiores utilizando máscara ou magnificação da imagem.
}

Unitermos: Interpretação radiográfica; Magnificação; Odontometria; Reprodutibilidade. 


\section{INTRODUCTION}

Although the success of endodontic therapy frequently depends on an accurate measurement of the distance from the tip of the endodontic file to the radiographic apex of the tooth, it is not always easy to determine the precise location of these structures on the radiograph.

The difficulty in visualizing the radiographic apex and tip of the file are related to many factors, including the gauge of the file, the quality of radiographic image, the root position in the arch and the method of radiographic interpretation.

Many authors have recommended the use of magnifying glasses in radiographic interpretation in order to maximize perception of detailed information ${ }^{2,5,6,8,12,15,17}$. Others encourage the use of a viewing device that simultaneously enlarges the radiographic image and blocks out extraneous light that could distract from the viewing procedures, thus increasing the visualization of small or low-contrast structures ${ }^{3,7,16}$. With respect to endodontic procedures, Ingle, et al. ${ }^{8}$ (1994) stated that blocking the light from around the radiograph is very important in allowing the observer a better definition of the root apex and the endodontic file. Therefore, it is expected that use of a light-blocking viewing device can improve the radiographic interpretation in endodontic practice, by increasing the visual acuity of the clinicians ${ }^{7}$.

No studies were found in the literature comparing the efficacy of two techniques of image magnification, simple magnifying lens or light-blocking magnifying viewing device, for the task of measuring the distance between the root apex and the tip of an endodontic file in the root. Therefore, even though magnification of the radiographic image is a known procedure among radiologists and endodontists, it seemed appropriate to perform such study to determine the optimum interpretation condition for this important diagnostic task.

The aim of this study was to compare the efficacy of three conditions of image interpretation for radiographic root measurements: visual without viewbox mask and magnification, magnifying glass with mask, and lightblocking viewing device incorporating a magnifying lens, calculating the intra-observer reproducibility of the measurements in each of the viewing methods and determining whether there are differences among the three methods.

\section{MATERIALAND METHODS}

The sample consisted of 30 intra-operative periapical radiographs of maxillary central and lateral incisors, obtained from the Endodontic department files. The radiographs were selected on the basis of image quality, judged by ideal contrast and density and lack of geometric distortion. The definition of the root apex and the 10-15 gauge endodontic files was also considered in selecting the radiographs.

The radiographs, mounted in opaque film mounts and numbered, were placed one at a time on a standard viewbox and measured, in $\mathrm{mm}$, from the tip of the file to the radiographic apex, by one of the authors ( $\mathrm{MO}$ ), an endodontist with 25 years of experience, using a caliper (Fowler, Ultra-Call Mark III, Switzerland), in a quiet room under reduced lighting.

Each experimental viewing and measuring period required three days to complete. On each day, three separate measurements were made of the distance between the root apex and the file tip on each of the 30 radiographs, for a total of 90 measurements, using the caliper as described above. The three measurements for each tooth were averaged and the mean used for further calculations. Each day, a different viewing condition was used and the order of the radiographs was varied to minimize observer bias. After a 12-day period, the three days of measurement were repeated.

Three experimental viewing conditions were used:

1) standard viewbox without masking of background light around the radiograph and without magnification (Visual);

2) standard viewbox with use of a magnifying lens of $2.5 \mathrm{x}$ and with background light masked (Magnification); and

3) viewer device that restricts room lighting and enlarges the image by a magnifying lens of $1.75 x$ (Viewer) (MammoMask, Broadwest Corp., New York, USA).

\section{Statistical Analysis}

For each observation period of each viewing technique, the mean and standard deviation of the measurements of all 30 radiographs were calculated and used for descriptive analysis. Two-way analysis of variance (ANOVA) was used to evaluate intra-observer and inter-method agreement of the measurements. The measurement error (D) was estimated by Dalhberg's formula:

$$
D=\sqrt{\frac{\sum d^{2}}{2 n}}
$$

where:

$d$ =difference between the measurements in the first and second occasions, and

$n=$ sample size

All statistical analysis were performed with the software STATA (Stata Reference Manual, Release 3.1, $6^{\text {th }}$ edn, 1993. Stata Corporation, College Station, Texas, USA)

\section{RESULTS}

The means and standard deviations of the measurements for both viewing sessions with all three viewing conditions can be seen in Table 1 .

The results are similar for all series of measurements.

Results from the analysis of variance are shown in Table 2, with no significant differences found between 
measurement sessions, viewing methods, or interaction between observation session and method ( $p>0.05$ ).

The intra-observer measurement error was $0.02 \mathrm{~mm}$ for both the Visual and the Magnification methods and $0.01 \mathrm{~mm}$ for the Viewer.

TABLE 1- Mean ( $\bar{X})$ and standard deviation (sd) of the measurements between endodontic file and radiographic apex for two reading sessions and three viewing conditions

\begin{tabular}{|c|c|c|c|c|c|c|}
\hline \multirow[t]{2}{*}{$\begin{array}{l}\text { Reading } \\
\text { session }\end{array}$} & \multicolumn{2}{|c|}{ Visual $^{a}$} & \multicolumn{2}{|c|}{ Magnification $^{b}$} & \multicolumn{2}{|c|}{ Viewer } \\
\hline & $\bar{x}$ & sd & $\bar{x}$ & $\mathrm{sd}$ & $\bar{x}$ & sd \\
\hline $1^{\text {st }}$ & 2.14 & 1.09 & 2.16 & 1.05 & 2.10 & 1.09 \\
\hline $2^{\text {nd }}$ & 2.17 & 1.11 & 2.05 & 1.07 & 2.13 & 1.09 \\
\hline
\end{tabular}

a: viewbox without mask or magnification

b: viewbox with mask and magnifying lens

c: light-blocking magnifying image viewer

TABLE 2- Measurements from interpretation (I) and method (M) in two-way analysis of variance

\begin{tabular}{lllll}
\hline $\begin{array}{l}\text { Source } \\
\text { of variation }\end{array}$ & d.f. & S.S. & M.S. & F \\
\hline I & 1 & 0.0816 & 0.0816 & $0.07 \mathrm{~ns}$ \\
M & 2 & 0.0734 & 0.0367 & $0.03 \mathrm{~ns}$ \\
IxM & 2 & 0.0252 & 0.0126 & $0.01 \mathrm{~ns}$ \\
Residual & 174 & 205.4529 & 1.1808 & \\
TOTAL & 179 & - & - & - \\
\hline
\end{tabular}

ns: non significant, $p>0.05$

I= interpretation session

$\mathrm{M}=$ viewing method

\section{DISCUSSION}

Although Ingle, et al. ${ }^{8}$ (1994) have suggested the use of magnifiyng lens for radiographic interpretation of the root apex and endodontic file, the results of this study showed no significant differences between the three radiographic viewing conditions studied. Thus, when the radiographs were interpreted with or without a mask and with or without magnification, the measurement results were similar for this specific diagnostic task.

Many textbooks recommend the use of magnification when interpreting dental radiographs. Perception of objects on a radiograph is best when the size of the object has a spatial frequency of about 0.5 cycles $/ \mathrm{mm}$ (about the size of a thick trabecula of mandibular bone) at a viewing distance of $50 \mathrm{~cm}^{14}$. Perception of smaller objects is best accomplished with either magnification or a decreased viewing distance. Many people also find it more comfortable to view an enlarged image, particularly as the eye begins to age and develop presbyopia ${ }^{4}$.

The use of a magnifying lens can also increase the concentration of the observer by limiting the field of view visible at any one time. While this is probably important in any type of radiographic interpretation, it is of particular concern when interpreting a small area, such as the apex of a root.

Although imaging theory suggests that magnification is helpful in radiographic interpretation, there have been few studies published in the literature where this has actually been tested. Some authors ${ }^{1,9}$ evaluated the use of magnification alone in the interpretation of periapical lesions and dental caries, respectively, and neither found any advantage to magnification when used with film images. On the other hand, apparently magnification is useful when interpreting dental caries on digital images ${ }^{10,11,13}$.

It has also been stated that radiographic interpretation is best done in a room with reduced overhead lighting and with the use of a mask to block the excess light from the viewbox around the radiograph. As the eye adapts to increased luminance, the pupil size decreases and the ability to perceive structures with low image contrast also decreases.

Some authors ${ }^{3,7,16}$ have recommended the use of a special viewing device that incorporates both a magnifying lens and a method of blocking all extraneous light from the eye of the observer. This device offers the benefits discussed above with the convenience of being able to use it in any viewing environment, even when it is not possible to dim the overhead, such as in a clinic.

One probable reason that this study did not show any benefits to magnification or masking is the nature of the diagnostic task. In this study the observer had to make a measurement of a distance between two points, the radiographic apex of the tooth and the tip of the endodontic file. This latter point is easier to visualize on a radiograph than many other structures because the file is radiopaque and has a well-defined border. Viewing conditions appear to be less important for interpreting high-contrast objects than for low-contrast ones, such as dental caries.

It is also possible that the results of this study may have been affected by the experience of the observer, who has worked as an endodontist for 25 years and who measures radiographs every day in his practice. It is not clear whether less experienced observers would produce the same results with the three conditions of interpretation used in this study.

Another possible influence on the results of this study is the use of radiographs of maxillary anterior teeth only. Detecting the radiographic apex of posterior teeth is frequently more difficult due to image distortion and superimposition of other structures. It is possible that the different viewing conditions might have produced a difference in measurements if maxillary molars had been used instead of incisors.

Based on the results of this study, including the 
extremely low intra-observer measurement error in all viewing methods, there does not seem to be any advantage in using viewbox masking or magnification for measuring the distance between the end of the endodontic file and the root apex. However, this is a very specialized diagnostic task, involving high contrast objects, and may not be representative of other radiographic interpretation situations.

Repeating the study with other groups of teeth, other types of diagnostic problems and observers with a range of experience levels may help determining whether the imaging theory discussed in many textbooks has any practical application in clinical practice.

\section{CONCLUSION}

In conclusion, there does not seem to be any advantage in using viewbox masking, magnification or viewing device for measuring the distance between the end of the endodontic file and the root apex in maxillary incisors.

\section{ACKNOWLEDGMENTS}

We wish to thank and express our sincere gratitude to Dr. Sharon Brooks for her valuable suggestions and helping in the English version. The scholarship from CAPES and the travel fund for IADR presentation from FAPESP \# 99/ 12625-6.

\section{REFERENCES}

1- Antrim DD. Reading the radiograph: a comparison of viewing techniques. J Endod 1983;9:502-5.

2- Arnold LV. The radiographic detection of initial carious lesions on the proximal surfaces of teeth. Part II: The influence of viewing conditions. Oral Surg Oral Med Oral Pathol 1987;64:232-40.

3- Brynolf I. Improved viewing facilities for better roentgenodiagnosis. Oral Surg Oral Med Oral Pathol 1971;32:808-11.

4- Burton JF, Bridgman GF. Presbyopia and the dentist: the effect of age on clinical vision. Int Dent J 1990;40:303-12.

5- Christensen GJ. Dental radiographs and dental caries: a challenge. J Am Dent Assoc 1996;127:792-3.

6- Farman AG, Nortjé CJ, Wood RE. Principles of image interpretation. In: Goaz PW, White SC. Oral Radiology: principles and interpretation. St Louis: Mosby; 1994. p.291-305.

7- Gibbs SJ. Principles of radiographic interpretation. In: Goaz PW, White SC. Oral Radiology: principles and interpretation. St. Louis: Mosby; 1982. p.137-150.

8- Ingle JI, Walton RE, Goerig AC,Neaverth EJ, Lambert GL, Lambert $\mathrm{C}$ et al. Preparation for endodontic therapy. In: Ingle JI, Backland LK. Endodontics. Philadelphia: Williams \& Wilkins; 1994. p. 5391
9- McAndrew R, Longbottom C Magnification as an aid to caries diagnosis: an in-vitro study [Abstract 176]. J Dent Res 1993;72:708.

10- Møystad A, Svanaes DB, Larheim TA, Gröndahl H-G. Effect of image magnification of digitized bitewing radiographs on approximal caries detection: an in vitro study. Dentomaxillofac Radiol 1995;24:255-9.

11- Scaf G, Kantor ML, Walsh SJ. Effect of magnification on caries detection with RadioVisioGraph (R.V.G) [Abstract 1217]. J Dent Res 1993; 72:255 [Presented at $71^{\text {st }}$ Annual Meeting of the International Association for Dental Research, 1993 March 10-14, Chicago]

12- Scaf G, Macedo ES, Loffredo LCM. Efeito da magnificação ótica da imagem radiográfica na detecção de cáries proximais. Rev Odontol UNESP 1998;27:437-48.

13- Svanaes DB, Møystad A, Risnes S, Larheim TA, Gröndahl HG. Intraoral storage phosphor radiography for approximal caries detection and effect of image magnification: comparison with conventional radiography. Oral Surg Oral Med Oral Pathol Oral Radiol and Endod 1996;82:94-100

14- Van Nes FL, Bouman MA. Spatial modulation transfer in the human eye. J Opt Soc Am 1967;57: 401-6. In: Goaz PW, White SC. Oral Radiology: principles and interpretation. St. Louis: Mosby; 1982. p.137-150

15- Walton RE. Endodontic Radiography. In Walton RE, Torabinejad M. Principles and Practice of Endodontics. Philadelphia: Saunders; 1996. p.132-51.

16- Weisman MI. A superior magnifier for viewing radiographs. J Endod 1980;6:885.

17- White SC, Pharoah MJ. Oral Radiology: principles and interpretation. St Louis: Mosby; 2000. p.256-70 